\title{
Receptury zaczynów do uszczelniania kolumn rur posadowionych w otworach wierconych w skałach chłonnych
}

\section{Recipes of cement slurries for sealing pipe columns in boreholes drilled in absorptive rocks}

\author{
Marcin Kremieniewski \\ Instytut Nafty i Gazu - Państwowy Instytut Badawczy
}

\begin{abstract}
STRESZCZENIE: Uszczelnienie kolumny rur okładzinowych w otworach wierconych w rejonie występowania skał chłonnych może przysporzyć wielu problemów. Głównym utrudnieniem jest możliwość ewentualnej ucieczki cementu w strefę chłonną i w konsekwencji zanik cementu i utrata cyrkulacji, efektem czego będzie brak uszczelnienia danego interwału. W celu ograniczenia tego niekorzystnego zjawiska ucieczki cementu w strefy chłonne opracowywane są receptury zaczynów o obniżonej gęstości. Tego rodzaju zaczyny lekkie pozwalają na znaczne obniżenie ciśnienia hydrostatycznego w wypełnianej przestrzeni pierścieniowej otworu, dzięki czemu zachowana zostaje równowaga w układzie ciśnienie złożowe-ciśnienie hydrostatyczne. Podczas projektowania receptury zaczynu lekkiego stosuje się domieszki lekkie, których obecność w recepturze zaczynu powoduje obniżenie jego gęstości. Wprowadzenie takich lekkich frakcji może jednak niekiedy skutkować znacznym sedymentowaniem płynnego zaczynu i wzrostem jego parametrów reologicznych. Jest to niekorzystne, ponieważ zaczyn taki będzie wówczas wymagał zastosowania wyższych wydatków tłoczenia, co może skutkować wzrostem oporów hydraulicznych i niepożądanym wniknięciem cementu w strefy chłonne. Ponadto płaszcz cementowy powstały z zaczynów lekkich charakteryzuje się gorszymi wartościami parametrów mechanicznych i strukturalnych. W celu wyeliminowania tych niekorzystnych czynników, receptura zaczynu cementowego musi być opracowywana w taki sposób, aby jej parametry odpowiadały konkretnym warunkom otworowym, co zostało omówione w niniejszej publikacji. Problematyka dotycząca receptur zaczynów przeznaczonych do uszczelniania kolumn rur posadowionych w otworach wierconych w skałach chłonnych jest ciągle aktualna i wymaga prowadzenia badań nad nowymi zagadnieniami. Dlatego też w niniejszym artykule przedstawione zostały wyniki prac badawczych nad opracowaniem nowych zaczynów przeznaczonych do uszczelniania kolumn rur okładzinowych posadowionych w tego rodzaju formacjach geologicznych. Opracowano cztery receptury zaczynów, których parametry porównywano do receptury kontrolnej. Do sporządzania zaczynów użyto zarówno stosowane dotychczas, jak również nowe lekkie dodatki wypełniające i środki pozwalające na uzyskanie homogenicznej struktury. Zaprojektowano nowe receptury zaczynów dla warunków otworowych o temperaturze około $50^{\circ} \mathrm{C}$ i ciśnieniu około $10 \mathrm{MPa}$. Przeprowadzono badania stabilności sedymentacyjnej zaczynów oraz badania parametrów decydujących o efektywności uszczelniania. Dla próbek stwardniałych zaczynów wykonano badania porowatości i na podstawie uzyskanych wyników określono jednorodność struktury tworzącego się płaszcza cementowego.
\end{abstract}

Słowa kluczowe: zaczyn cementowy, zaczyn lekki, otwór wiertniczy, cementowanie otworów wiertniczych, skały chłonne, ucieczki cementu.

ABSTRACT: Sealing the casing pipe column in holes drilled in the area of absorptive rocks can cause many problems. The main difficulty is the possible escape of cement in the absorption zone and, consequently, the disappearance of cement and loss of circulation, the effect of which will be the lack of sealing the given interval. In order to reduce this phenomenon of the escape of cement into absorptive zones, the recipes of slurries with reduced density are developed. Such lightweight slurries allow to reduce the hydrostatic pressure in the space of the annular opening, thanks to which the balance in the system of the reservoir pressure - hydrostatic pressure is preserved. When designing lightweight cement slurry, light admixtures are used that reduce density. However, the introduction of such light fractions can sometimes result in a strong sedimentation of the liquid slurry and an increase in its rheological parameters. This is disadvantageous, because the slurry will then require the use of expensive pressing, which can cause an increase in hydraulic resistance and penetration of cement into the absorptive zones. In addition, the cement coat made of lightweight slurries is characterized by poorer values of mechanical and structural parameters. In order to eliminate these unfavorable factors, the cement slurry must be developed so that its parameters correspond to the specific borehole conditions, as discussed in this publication. Problems concerning the recipes of cement slurries for sealing the columns of pipes set in holes drilled in absorptive rocks are still valid and require research on new issues. Therefore, the article presents the results of research works on the development of new cement slurries intended for sealing the columns of casing pipes placed in such geological

Autor do korespondencji: M. Kremieniewski, e-mail: marcin.kremieniewski@inig.pl

Artykuł nadesłano do Redakcji 26.03.2019 r. Zatwierdzono do druku 22.07.2019 r. 
formations. Four leaven formulas were developed, whose parameters were compared to the control recipe. Previously used and new lightweight filler additives and the means to obtain a homogeneous structure were used to prepare the leaven. New recipes for cement slurries were designed for borehole conditions with a temperature of approx. $50^{\circ} \mathrm{C}$ and a pressure of approx. $10 \mathrm{MPa}$. Sedimentation stability tests of cement slurries and testing of parameters determining the effectiveness of sealing were carried out. The porosity tests were carried out for samples of hardened slurries and the homogeneity of the structure of the cement coat formed was determined based on the obtained results.

Key words: cement slurry, lightweight slurry, borehole, well cementing, absorptive rocks, cement escapes.

\section{Wprowadzenie}

Odpowiednio zaprojektowana, a następnie przeprowadzona operacja rurowania i cementowania poszczególnych kolumn rur okładzinowych w otworze wiertniczym, a szczególnie kolumny rur eksploatacyjnych wpływa na efektywność prac poszukiwawczych oraz wierceń na nowo odkrytych bądź już eksploatowanych złożach. Tematyka dotycząca prawidłowego zarurowania i uszczelnienia kolumny eksploatacyjnej nabiera szczególnego znaczenia na złożach wierconych w strefach chłonnych. Poprawnie przeprowadzony zabieg cementowania kolumny eksploatacyjnej zależy nie tylko od fachowej wiedzy specjalistów wiertniczych, ale w decydującej mierze od posiadanego wyposażenia. Technologia cementowania otworów wiertniczych w rejonie występowania skał chłonnych nie uległa zasadniczym zmianom w porównaniu z innymi zagadnieniami techniki wiercenia. Obserwuje się natomiast różnice w rodzaju stosowanych zaczynów cementowych (Stryczek et al., 2016; Kremieniewski, 2017a). Obecnie dostępnych jest wiele nowych opracowań teoretycznych i nowości technologicznych w zakresie sprzętu technicznego, materiałów uszczelniających, a szczególnie programów symulacyjnych dotyczących projektowania i wykonywania procesu cementowania otworów wiertniczych (Peng i Jacobsen, 2013; Kremieniewski, 2018;). W latach 60. krajowy poziom technologii odbiegał od poziomu światowego w zakresie przedsięwzięć technologicznych przy rurowaniu i cementowaniu kolumn rur okładzinowych w rejonach występowania skał chłonnych ze względu na brak potrzebnego sprzętu, jakim były pakery i manszety cementacyjne. Problemy te jednak w znacznym stopniu zostały rozwiązane dzięki współpracy Instytutu Górnictwa Nafty i Gazu w latach 1986-1989 (obecnie Instytutu Nafty i Gazu - Państwowego Instytutu Badawczego) z Polskim Górnictwem Nafty i Gazu. Opracowana została technologia, zaprojektowano i wykonano niezbędny sprzęt, a następnie przeprowadzono próby otworowe w otworze S-NA 44 i 46 (zastosowany osprzęt rur 65\%). Zaznaczyć należy, że do chwili obecnej trwa współpraca INiG - PIB oraz PGNiG, w ramach której są opracowywane i modyfikowane specjalistyczne receptury cieczy wiertniczych i zaczynów cementowych przeznaczonych do uszczelniania kolumn rur posadowionych w zróżnicowanych warunkach geologiczno-złożowych (Ciechanowska et al., 2008; Dohnalik i Zalewska, 2013; Kremieniewski, 2019).
W rejonach występowania skał chłonnych wpływ zaczynu cementowego na strefę przyodwiertową w horyzontach produktywnych może przysparzać wielu problemów. Związane jest to z możliwością występowania zaników i utraty cyrkulacji podczas cementowania. W takim przypadku istnieją metody na przeciwdziałanie temu zjawisku. Pierwszą jest utrzymanie ciśnienia poniżej maksymalnej ekwiwalentnej gęstości płuczki poprzez obniżenie gęstości zaczynu cementowego, zmniejszenie wysokości kolumny cementu lub ograniczenie oporów ciśnienia w rurach i przestrzeni pierścieniowej (Nelson et al., 1990; Gawlik i Szymczak, 2006; Stryczek et al., 2009; Kremieniewski et al., 2017). W tym celu stosuje się lekkie dodatki wypełniające, dzięki którym możliwe jest obniżenie gęstości zaczynu oraz specjalne dodatki, które powodują powstawanie tiksotropowych właściwości zaczynu (Stryczek et al., 2005; Kremieniewski i Rzepka, 2017; Kremieniewski, 2017b). Na podstawie danych uzyskanych z nowoczesnych programów symulacyjnym (rys. 1) pozwalających na obliczenie przewidywanych wartości ciśnienia wgłębnego w danym interwale możliwe jest dokładne rozpoznanie, jakie parametry zaczynu powinny
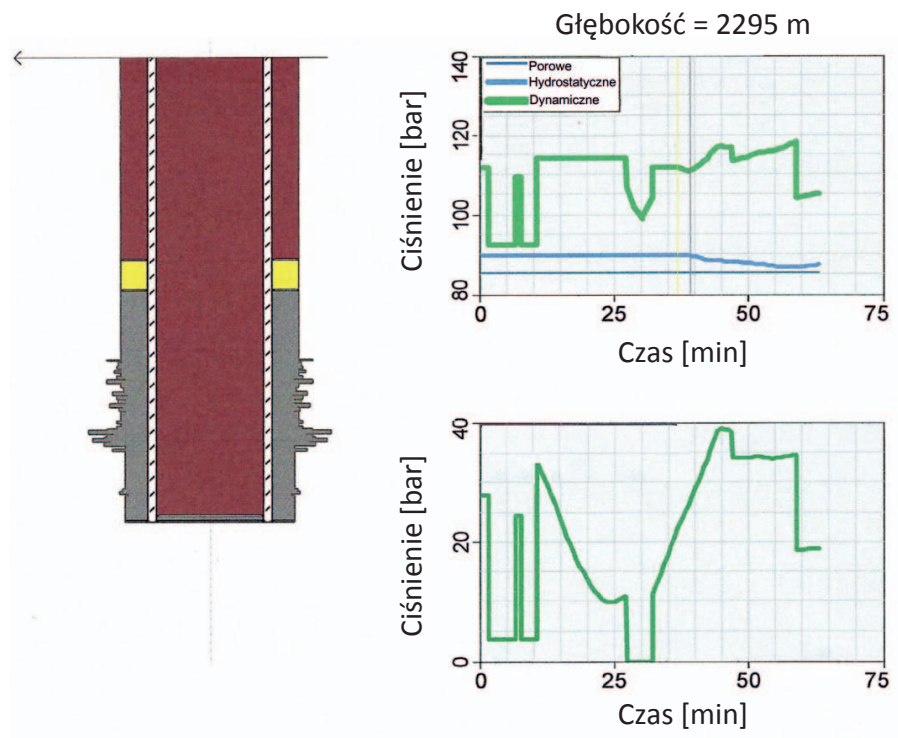

Rys. 1. Przykładowe dane uzyskane z oprogramowania symulacyjnego dla cementowania sekcji rur w głębokości 2295 metrów (widoczny przebieg wartości ciśnień w trakcie tłoczenia zaczynu cementowego)

Fig. 1. Sample data from simulation software for cementing pipe sections at a depth of 2295 meters (visible course of pressures during the pressing of cement slurry) 
być dobrane w celu utrzymania odpowiedniego ciśnienia hydrostatycznego i wyeliminowania ucieczki cementu dla konkretnego otworu wierconego w strefie występowania skał chłonnych. Oprócz odpowiedniej regulacji gęstości zaczynu istotny jest również prawidłowy dobór parametrów reologicznych, co jest korzystne z punktu widzenia możliwości obniżenia oporów hydraulicznych podczas tłoczenia zaczynu cementowego (Wiśniowski et al., 2007; Stryczek et al., 2014; Kremieniewski, 2017c).

Zagraniczne firmy (Dowell, Halliburton), które wykonują rurowanie oraz prowadzą zabiegi cementowania otworów wiertniczych, produkują różnego rodzaju sprzęt, który pozwala na wykonanie zabiegów cementowania kolumn rur w horyzontach występowania skał chłonnych. W krajowym wiertnictwie naftowym problem ochrony horyzontów produktywnych przed szkodliwym działaniem zaczynu cementowego był dotychczas rozwiązywany poprzez (Nelson et al., 1990):

- dwustopniowe cementowanie kolumny rur;

- stosowanie lekkich zaczynów cementowych;

- zapuszczanie i cementownie kolumny traconej;

- stosowanie odwrotnego /lewego/ cementowania kolumny rur.

Rurowanie i cementowanie otworów wiertniczych w warstwach występowania skał chłonnych ciągle stanowi jeden z poważniejszych i trudnych do rozwiązania problemów. Dlatego też w dalszej części publikacji omówione zostały wyniki badań nad opracowaniem nowych receptur lekkich zaczynów cementowych dostosowanych do konkretnych warunków otworowych, przeznaczonych do stosowania podczas uszczelniania kolumn rur okładzinowych w rejonie występowania skał o znacznej chłonności.

\section{Przebieg prac badawczych}

Prace badawcze na podstawie, których opracowano receptury zaczynów przeznaczone do uszczelniania kolumn rur posadowionych w otworach wierconych w skałach chłonnych zostały zrealizowane w Laboratorium Zaczynów Uszczelniających INiG - PIB w oparciu o normy: PN-85/G-02320 Cementy $i$ zaczyny cementowe do cementowania w otworach wiertniczych; PN-EN 10426-2 Przemyst naftowy i gazowniczy. Cementy i materialy do cementowania otworów. Część 2: Badania cementów wiertniczych oraz API SPEC 10 Specification for materials and testing for well cements.

Celem zaprezentowanego w niniejszej publikacji cyklu badawczego było opracowanie receptur zaczynów lekkich, które znajdują przeznaczenie do uszczelniania otworów wierconych w strefach chłonnych. Podczas projektowania nowych receptur zastosowano dodatki i domieszki pozwalające na uzyskanie niskiej gęstości zaczynu oraz pozwalające na uzyskanie wymaganych parametrów technologicznych dostosowanych do określonych warunków geologiczno-technicznych. Trudnością podczas projektowania receptur zaczynów o obniżonej gęstości, było wyeliminowanie nadmiernego frakcjonowania struktury płynnego zaczynu objawiającego się nadmierną sedymentacją oraz wydzielaniem się wody wolnej. W celu wyeliminowania niepożądanego zjawiska nadmiernego frakcjonowania cząstek o różnych gęstościach skoncentrowano się na odpowiednim doborze ilościowym poszczególnych dodatków i domieszek oraz zastosowano środki przeciwdziałające sedymentacji. Podczas projektowania receptury zaczynu istotne było uzyskanie wyższych wartości wytrzymałości strukturalnej, dzięki czemu zaczyn wykazywał

Tabela 1. Składy wytypowanych zaczynów dla warunków otworowych o temperaturze około $50^{\circ} \mathrm{C}$ i ciśnieniu około $10 \mathrm{MPa}$

Table 1. Compositions of selected slurries for borehole conditions with a temperature of approx. $50^{\circ} \mathrm{C}$ and a pressure of about $10 \mathrm{MPa}$

\begin{tabular}{|c|c|c|c|c|c|}
\hline SKLAD & $\begin{array}{c}\text { ZACZYN } 1 \\
\text { bazowy }\end{array}$ & ZACZYN 2 & ZACZYN 3 & ZACZYN 4 & ZACZYN 5 \\
\hline Woda wodociągowa & 0,98 & 1,0 & 0,90 & 1,0 & 0,90 \\
\hline Bentonit (bwow) & $1,5 \%$ & $2,0 \%$ & $1,5 \%$ & $1,0 \%$ & $0,5 \%$ \\
\hline Środek odpieniający & $0,5 \%{ }^{*}$ & $0,5 \%$ & $0,5 \%$ & $0,5 \%$ & $0,5 \%$ \\
\hline Środek upłynniający & $0,1 \%{ }^{*}$ & $0,3 \%$ & $0,3 \%$ & $0,4 \%$ & $0,4 \%$ \\
\hline Środek antyfiltracyjny & $0,5 \%{ }^{*}$ & $0,4 \%$ & $0,4 \%$ & $0,4 \%$ & $0,3 \%$ \\
\hline Środek opóźniający wiązanie & $0,45 \%^{*}$ & - & - & - & - \\
\hline $\mathrm{CaCl}_{2}$ & - & $2,0 \%$ & $2,0 \%$ & $2,0 \%$ & $3,0 \%$ \\
\hline Lateks & - & - & $10,0 \%$ & - & $1,0 \%$ \\
\hline Stabilizator lateksu & - & - & $1,0 \%$ & - & $10,0 \%$ \\
\hline Mikrosfera & $15,0 \%$ & $40,0 \%$ & $40,0 \%$ & - & \\
\hline Perlit filtracyjny & - & - & - & $10,0 \%$ & $10,0 \%$ \\
\hline Mikrocement & $10,0 \%$ & - & - & - & - \\
\hline Cement CEM G & $100,0 \%$ & $100,0 \%$ & $100,0 \%$ & $100,0 \%$ & 100,0 \\
\hline
\end{tabular}

*Zastosowano inny rodzaj środków (DS) 
Tabela 2. Parametry badanych receptur zaczynów dla warunków otworowych o temperaturze około $50^{\circ} \mathrm{C}$ i ciśnieniu około $10 \mathrm{MPa}$

Table 2. Parameters of the tested slurries for borehole conditions with a temperature of approx. $50^{\circ} \mathrm{C}$ and a pressure of about $10 \mathrm{MPa}$

\begin{tabular}{|c|c|c|c|c|c|c|}
\hline \multicolumn{2}{|l|}{ Parametr } & $\begin{array}{c}\text { ZACZYN } 1 \\
\text { bazowy }\end{array}$ & ZACZYN 2 & ZACZYN 3 & ZACZYN 4 & ZACZYN 5 \\
\hline \multicolumn{2}{|l|}{ Gęstość $\left[\mathrm{kg} / \mathrm{m}^{3}\right]$} & 1440 & 1270 & 1220 & 1300 & 1290 \\
\hline \multicolumn{2}{|l|}{ Odstój wody [\%] } & 0,4 & 0,0 & 0,0 & 0,0 & 0,0 \\
\hline \multicolumn{2}{|l|}{ Filtracja $\left[\mathrm{cm}^{3} / 30 \mathrm{~min}\right]$} & 290 & 384 & 180 & 304 & 149 \\
\hline \multicolumn{2}{|c|}{ Lepkość plastyczna $[\mathrm{mPa} \cdot \mathrm{s}]$} & 54,0 & 90,0 & 94,5 & 112,5 & 115,0 \\
\hline \multicolumn{2}{|l|}{ Granica płynięcia [Pa] } & 1,44 & 21,6 & 10,8 & 16,56 & 12,72 \\
\hline \multicolumn{2}{|c|}{ Wytrzymałość strukturalna [Pa] } & 7,2 & 31,2 & 18,7 & 26,4 & 21,1 \\
\hline \multirow{3}{*}{$\begin{array}{l}\text { Stabilność sedymentacyjna } \\
\text { Gęstość w części kolumny } \\
{\left[\mathrm{kg} / \mathrm{m}^{3}\right]}\end{array}$} & góra & 1410 & 1270 & 1220 & 1300 & 1290 \\
\hline & środek & 1440 & 1270 & 1220 & 1300 & 1290 \\
\hline & dół & 1470 & 1270 & 1220 & 1300 & 1290 \\
\hline \multirow{2}{*}{$\begin{array}{l}\text { Czas gęstnienia [godz:min] } \\
\left(t=50^{\circ} \mathrm{C}^{*}, p=10 \mathrm{MPa}\right)\end{array}$} & $30 \mathrm{Bc}$ & $4: 22$ & $2: 10$ & 4:01 & $2: 20$ & $3: 40$ \\
\hline & $100 \mathrm{Bc}$ & $4: 48$ & 3:03 & $4: 25$ & 3:01 & 3:56 \\
\hline
\end{tabular}

* Czas dojścia do temperatury w 50 minut

odpowiednią stabilność oraz w pewnym sensie cechy zaczynu tiksotropowego, co było korzystne z punktu widzenia stosowalności danej receptury w rejonie występowania skał chłonnych. W trakcie realizacji prac głównym badaniem było określenie gęstości, stabilności sedymentacyjnej oraz odstoju wody. Następnie po uzyskaniu wymaganych wartości pomiarowi poddano pozostałe parametry technologiczne zaczynu, decydujące o efektywności uszczelniania, tj.: parametry reologiczne zaczynu, filtracja zaczynu w warunkach dynamicznych oraz czas gęstnienia w warunkach otworopodobnych. W tabeli 1 przedstawiono składy receptur zaczynów, natomiast $\mathrm{w}$ tabeli 2 - uzyskane parametry technologiczne zaczynów. W publikacji zamieszczono tylko pozytywne rezultaty uzyskanych prac badawczych.

Receptury zaczynów cementowych przeznaczone do uszczelniania kolumn rur posadowionych w otworach wierconych w skałach chłonnych zestawiono w tabeli 1 . Zaczyn $\mathrm{nr} 1$ to receptura zastosowana do uszczelniania otworu SM1. Recepturę tego zaczynu przyjęto, jako zaczyn kontrolny w celu porównawczym. Zaczyn ten sporządzono na osnowie innego rodzaju środków (DS) niż środki użyte do sporządzania pozostałych receptur. Zaczyny nr 2 oraz 3 to receptury, w których gęstość regulowano poprzez wprowadzenie dodatku mikrosfer, natomiast receptury 4 i 5 to zaczyny z dodatkiem perlitu filtracyjnego. Wszystkie receptury sporządzono dla warunków otworowych o temperaturze około $50^{\circ} \mathrm{C}$ i ciśnieniu około $10 \mathrm{MPa}$.

Receptura kontrolna $\mathrm{nr} 1$ nie zawierała lateksu, natomiast posiadała $15 \%$ mikrosfer w celu obniżenia gęstości oraz $10 \%$ mikrocementu, którego zadaniem było doszczelnienie matrycy cementowej (tab. 1). Tak sporządzony zaczyn posiadał gęstość $1440 \mathrm{~kg} / \mathrm{m}^{3}$ i wykazywał znaczną $0,4 \%$-ową wartość odstoju wody. Zaczyn nie posiadał odpowiedniej stabilności sedymentacyjnej, gdzie podczas pomiaru gęstości w trzech

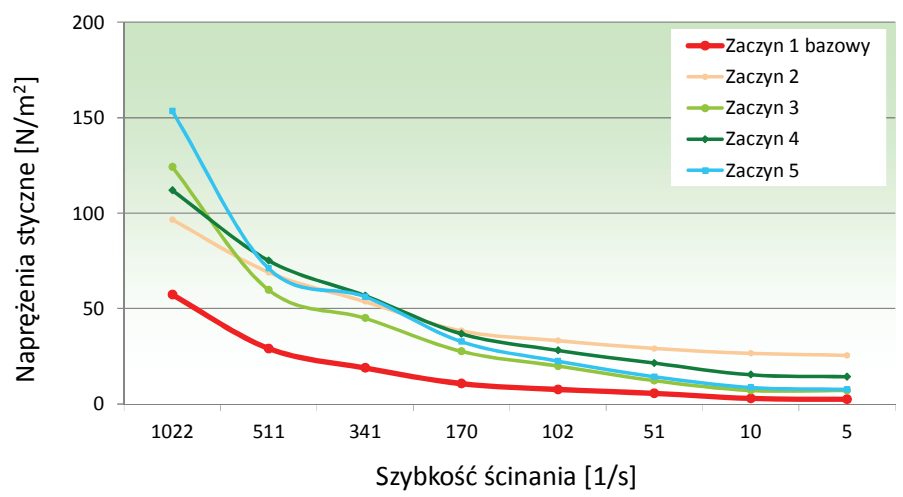

Rys. 2. Przebieg wartości krzywych płynięcia omawianych receptur zaczynów cementowych

Fig. 2. The course of values of the flow curves of the discussed cement slurries

punktach pomiarowych kolumny sedymentacyjnej uzyskano wartość $1410 \mathrm{~kg} / \mathrm{m}^{3}$ w części górnej, $1440 \mathrm{~kg} / \mathrm{m}^{3}$ w części środkowej oraz $1470 \mathrm{~kg} / \mathrm{m}^{3}$ w dolnej. Nadmierne frakcjonowanie zaczynu mogło być efektem niskich wartości parametrów reologicznych zaczynu, którego krzywa płynięcia posiadała najniższy z analizowanych zaczynów przebieg (rys. 2). W recepturze tej wartość granicy płynięcia wynosiła 1,44 Pa a wytrzymałość strukturalna była równa 7,2 Pa. Filtracja zaczynu w warunkach dynamicznych wynosiła $290 \mathrm{~cm}^{3} / 30 \mathrm{~min}$. Uzyskane wyniki badań zestawiono w tabeli 2 .

Zaczyn $\mathrm{nr} 2$ zawierał znacznie większą (40\%-ową) koncentrację mikrosfer, a w celu poprawy stabilności sedymentacyjnej zastosowano $2 \% \mathrm{BWOW}^{1}$ bentonitu. $\mathrm{Z}$ uwagi na

${ }^{1}$ BWOW z ang. by weight of water - w stosunku do ilości wody zarobowej w zaczynie 
obecność $2 \%$ chlorku wapnia użytego do skrócenia czasu wiązania, a jednocześnie powodującego zagęszczenie struktury zaczynu, to o poprawne wartości parametrów reologicznych zadbano stosując $0,3 \%$-ową koncentrację środka dyspergującego. W zaczynie nie zastosowano mikrocementu (tab. 1). Tak sporządzony zaczyn posiadał niższą gęstość niż zaczyn kontrolny $\left(1270 \mathrm{~kg} / \mathrm{m}^{3}\right)$. Jest to istotne, ponieważ uzyskanie tak niskich wartości gęstości zwiększa prawdopodobieństwo zachodzenia sedymentacji. Jednak podczas pomiaru tego parametru zaczyn wykazywał odpowiednią stabilność sedymentacyjną i we wszystkich punktach poboru próbki (góra, środek, dół) uzyskano tą samą wartość gęstości. Potwierdzeniem odpowiedniej stabilności sedymentacyjnej był również brak odstoju wody (tab. 2). Uzyskanie homogenicznej struktury zaczynu związane było z reologią zaczynu, którego krzywa płynięcia przedstawiona na rysunku 2 , jest wyżej usytuowana niż krzywa zaczynu kontrolnego. Wytrzymałość strukturalna zaczynu wynosiła $31 \mathrm{~Pa}$. Niestety ze względu na znaczną ilość mikrosfer, filtracja zaczynu była wyższa niż w recepturze kontrolnej i wynosiła $384 \mathrm{~cm}^{3} / 30 \mathrm{~min}$.

W celu obniżenia wartości filtracji poprzedniego zaczynu, a jednoczenie utrzymania optymalnych wartości pozostałych parametrów, zaprojektowano recepturę oznaczoną numerem 3, do której wprowadzono 10\% lateksu oraz zredukowano współczynnik wodno cementowy i zmniejszono ilość bentonitu (tab. 1). Wprowadzone zmiany skutkowały osiągnięciem jeszcze niższej gęstości, która wynosiła w tym zaczynie $1220 \mathrm{~kg} / \mathrm{m}^{3}$, przy jednoczesnym zachowaniu wymaganej stabilności sedymentacyjnej, mimo zmniejszenia się wartości wytrzymałości strukturalnej do 18,7 Pa (tab. 2). Zaczyn nie posiadał odstoju wody, a filtracja została zredukowana do wartości wynoszącej $180 \mathrm{~cm}^{3} / 30$ minut.

Kolejny zaczyn oznaczony numerem 4 to receptura, w której do obniżenia gęstości użyto niestosowany dotychczas dodatek perlitu filtracyjnego, oraz nie zastosowano lateksu (tab. 1). Obecność 10\%-owej koncentracji perlitu skutkowała uzyskaniem gęstości zaczynu $1300 \mathrm{~kg} / \mathrm{m}^{3}$. Jest to korzystne z ekonomicznego punktu widzenia, ponieważ we wcześniejszej recepturze, gęstość taką uzyskano przy dodatku $40 \%$ mikrosfer. Zaczyn na bazie perlitu posiadał jednakowe wartości w poszczególnych punktach pomiaru podczas badania stabilności sedymentacyjnej i nie wykazywał odstoju wody. Jednak brak dodatku lateksu skutkował znaczną wartością filtracji, która wynosiła $302 \mathrm{~cm}^{3} / 30 \mathrm{~min}$ (tab. 2)

W celu zredukowania wartości filtracji w kolejnej recepturze na bazie perlitu, oznaczonej nr 5 zastosowano 10\%-ową koncentrację lateksu. Ponadto zmniejszono współczynnik wodno cementowy, zastosowano $0,5 \%$ (BWOW) ilość bentonitu oraz zastosowano 3\% chlorku wapnia w celu uzyskania wymaganego czasu gęstnienia zaczynu. Skład zaczynu przedstawiono w tabeli 1. Wprowadzenie niniejszych modyfikacji skutkowało obniżeniem wartości filtracji z poprzedniej receptury i uzyskano $149 \mathrm{~cm}^{3} / 30 \mathrm{~min}$. Zaczyn posiadał gęstość $1290 \mathrm{~kg} / \mathrm{m}^{3}$ i wartość ta była stała niezależnie od punktu poboru próbki z poszczególnych części kolumny sedymentacyjnej. Zaczyn posiadał prawidłowe parametry reologiczne (tab. 2), a przebieg krzywej płynięcia przedstawiono na rysunku 2.

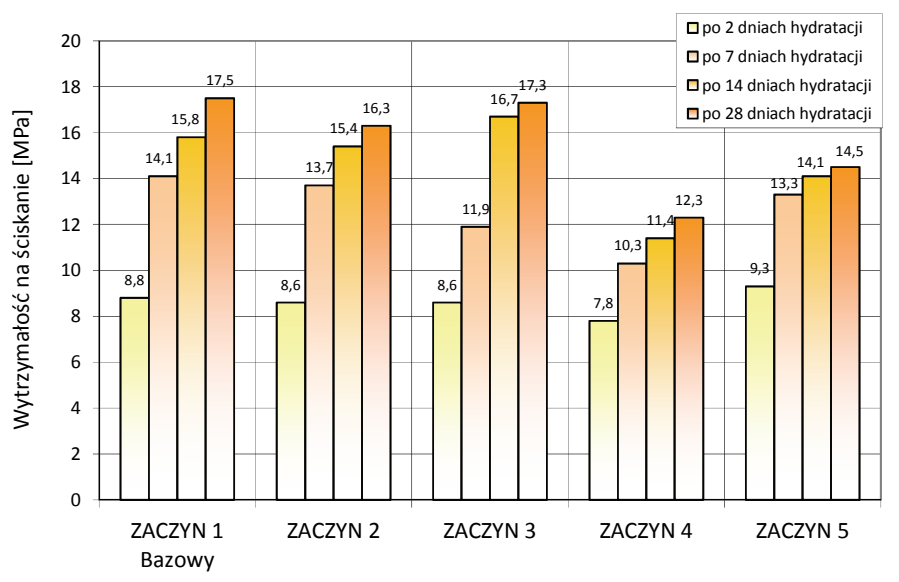

Rys. 3. Porównanie uzyskanych wartości wytrzymałości na ściskanie Fig. 3. Comparison of obtained compressive strength values

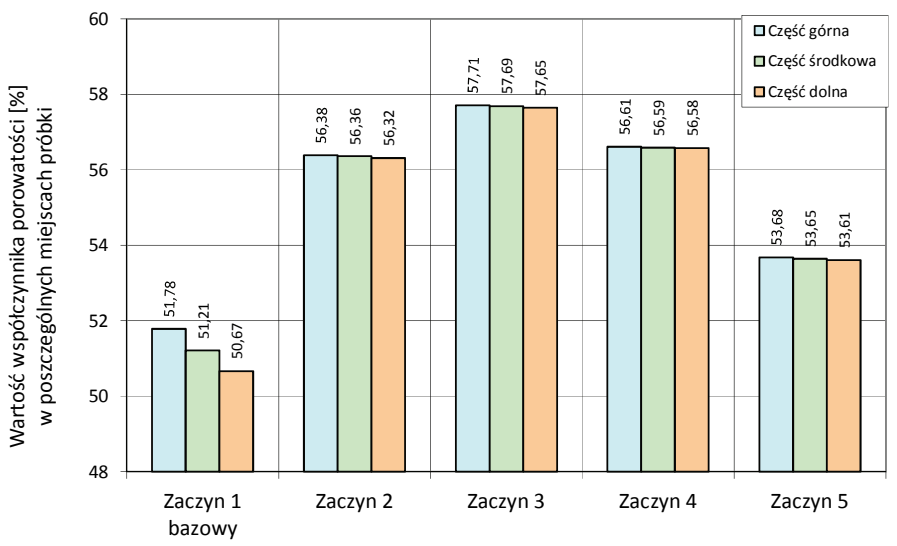

Rys. 4. Zestawienie wartości porowatości stwardniałego zaczynu w zależności od miejsca poboru próbki (izotropia struktury)

Fig. 4. Comparison of porosity values depending on the sampling point (structure isotropy)

Analizując uzyskane wyniki wartości parametrów mechanicznych (rys. 3) stwierdzono, że najwyższe wytrzymałości na ściskanie posiadały próbki stwardniałego zaczynu powstałego z próbki kontrolnej. Może być to tłumaczone najwyższą wartością gęstości, która w świeżym zaczynie wynosiła $1440 \mathrm{~kg} / \mathrm{m}^{3}$. Stwardniałe zaczyny oznaczone numerami 2 oraz 3, do których sporządzenia użyto $40 \%$ mikrosfery, posiadały nieznacznie niższe wartości wytrzymałości na ściskanie niż próbka kontrolna (zaczyn 1). Z kolei próbki z zaczynów, w których do obniżenia gęstości zastosowano $10 \%$ perlitu filtracyjnego, wykazywały najniższe wartości 
wytrzymałości na ściskanie spośród całej analizowanej grupy. Zaobserwowano, że w recepturach na bazie perlitu filtracyjnego, które zawierały dodatek lateksu uzyskano zadowalające wartości wytrzymałości w początkowym okresie wiązania po 2 i 7 dniach hydratacji. Takie zachowanie może być korzystne podczas projektowania receptur, w których wymagane jest szybkie uzyskanie podwyższonej wartości wczesnej wytrzymałości na ściskanie.

Z kolumny stwardniałego zaczynu o długości $30 \mathrm{~cm}$, który hydratyzował w ułożonym pionowo cylindrze (fot. 1) pobrano próbki do badań struktury porowej. Celem takich działań było zweryfikowanie homogeniczności struktury tworzącego się w otworze płaszcza cementowego. W próbce kontroInej oznaczonej numerem 1 uzyskano wartość porowatości wynoszącą 51,78\% w górnej części, 51,21\% w części środ-

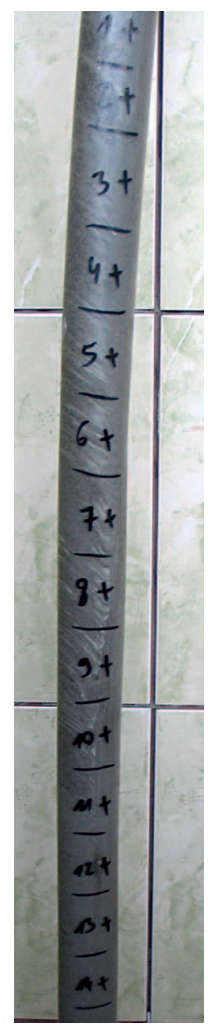

kowej oraz porowatość wynoszącą 50,67\% dla próbki pobranej z dolnej części cylindra. Uzyskane wartości potwierdzają anizotropię, która może występować w strukturze płaszcza cementowego powstałego z tego rodzaju zaczynu. Nowoopracowane receptury zaczynów oznaczone numerami od 2 do 5 charakteryzują się porównywalnymi wartościami porowatości, co świadczy o stabilności sedymentacyjnej płynnego zaczynu, która znajduje przełożenie na powstanie homogenicznej mikrostruktury płaszcza cementowego w przestrzeni pierścieniowej lub pozarurowej. Wartości porowatości próbek w zależności od miejsca poboru zestawiono na rysunku 4.

Fot. 1. Próbka stwardniałego zaczynu do badań porowatości w określonym punkcie pomiaru

Photo 1. A sample of a hardened slurry for porosity tests at a specific measurement point

\section{Wnioski}

Na podstawie zrealizowanych prac badawczych sformułowano następujące wnioski końcowe:

1) Zastosowanie dodatku lateksu do zaczynu cementowego powoduje obniżenie wartości filtracji, zarówno w zaczynie $\mathrm{z}$ dodatkiem mikrosfery, jak i z dodatkiem perlitu filtracyjnego.

2) Stabilność sedymentacyjna zaczynu cementowego jest uzależniona od jego parametrów reologicznych, głównie od wartości wytrzymałości strukturalnej i granicy płynięcia.

3) Zastosowanie $40 \%$ mikrosfer ceramicznych w celu obniżenia gęstości zaczynu cementowego odpowiada użyciu ok. 12\% perlitu filtracyjnego, przez co perlit wydaje się być bardziej ekonomicznym lekkim dodatkiem wypełniającym.

4) Zaczyny, w których do obniżenia gęstości stosowano perlit filtracyjny (zaczyn nr 4 i nr 5; tab. 2), posiadały niższe wartości filtracji niż odpowiadające im receptury sporządzone na bazie mikrosfer ceramicznych (zaczyny nr 2 i nr 3; tab. 2).

5) Zastosowanie w zaczynie cementowym perlitu filtracyjnego zamiast mikrosfer ceramicznych powoduje wzrost jego lepkości plastycznej.

6) Perlit filtracyjny powoduje nieznaczne skrócenie czasu gęstnienia zaczynu lateksowego (zaczyn 5) w porównaniu do dopowiadającej mu receptury z dodatkiem mikrosfer ceramicznych (zaczyn 3).

7) Próbki stwardniałego zaczynu uzyskane z zaczynu zawierającego $40 \%$ mikrosfer, posiadały nieznacznie niższe wartości wytrzymałości na ściskanie (po 2, 7, 14, 28 dniach hydratacji) niż próbka kontrolna. Gęstość zaczynu kontrolnego była jednak wyższa, co mogło znajdować przełożenie na wyższą wartość wytrzymałości na ściskanie.

8) Stwardniały zaczyn cementowy, powstały z zaczynów zawierających perlit filtracyjny posiadał niższe wartości wytrzymałości na ściskanie (po 14 i 28 dniach hydratacji) niż odpowiadające im próbki powstałe z zaczynu zawierającego mikrosfery ceramiczne.

9) Stwardniały zaczyn uzyskany z receptury na bazie perlitu filtracyjnego z dodatkiem lateksu (zaczyn 5) posiadał wyższe wartości wytrzymałości na ściskanie w początkowym okresie wiązania po 2 i 7 dniach hydratacji, niż odpowiadająca temu zaczynowi receptura $\mathrm{z}$ dodatkiem mikrosfer (zaczyn 3).

10) Struktura porowa próbki z zaczynu kontrolnego wykazywała anizotropię podczas badań porowatości (rys. 4), co było efektem nadmiernego frakcjonowania zaczynu w fazie płynnej.

11) Nowoopracowane receptury zaczynów z dodatkiem zarówno mikrosfer ceramicznych, jak i perlitu filtracyjnego wykazywały izotropową strukturę, czego dowodem było uzyskanie porównywalnych wartości porowatości w różnych punktach pomiaru (rys. 4).

Artykuł powstał na podstawie prac badawczych pt.: Analiza możliwości poprawy stabilności sedymentacyjnej zaczynów cementowych - praca INiG - PIB na zlecenie MNiSW; nr zlecenia: 36/ KW/16, nr archiwalny: DK-4100/36/16 oraz Analiza możliwości doszczelnienia mikrostruktury płaszcza cementowego za pomoca nowych domieszek drobnoziarnistych - praca INiG - PIB na zlecenie MNiSW; nr zlecenia: 0044/KW/19, nr archiwalny: DK-4100/34/19. 


\section{Literatura}

Ciechanowska M. (kier. zespołu), 2008. Analiza i ocena zagrożeń ekshalacjami gazu. Studium przypadku. Projekt EFRR Interreg III: Ekshalacje gazu ziemnego - polsko-ukraiński problem Przedgórza Karpat. Archiwum INiG - PIB, Kraków.

Dohnalik M., Zalewska J., 2013. Korelacja wyników laboratoryjnych uzyskanych metodą rentgenowskiej mikrotomografii, jądrowego rezonansu magnetycznego i porozymetrii rtęciowej. Nafta-Gaz, 10: 735-743.

Gawlik P., Szymczak M., 2006. Migracje gazowe w przestrzeniach międzyrurowych otworów realizowanych na Przedgórzu Karpat, Nafta-Gaz, 7-8: 349-358.

Kremieniewski M., 2017a. Poprawa stabilności sedymentacyjnej zaczynu cementowego. Nafta-Gaz, 4: 242-249. DOI: 10.18668/ NG.2017.04.04.

Kremieniewski M., 2017b. Wpływ perlitu pylistego na własności technologiczne zaczynu cementowego. Nafta-Gaz, 12: 943-952. DOI 10.18668/NG.2017.12.05.

Kremieniewski M., 2017c. Poprawa stabilności sedymentacyjnej zaczynów cementowych. Prace Instytutu Nafty $i$ Gazu - Państwowego Instytutu Badawczego, 216, DOI 10.18668/ PN2017.216.

Kremieniewski M., 2018. Poprawa wczesnej wytrzymałości mechanicznej płaszcza cementowego powstałego z zaczynu lekkiego. Nafta-Gaz, 8: 599-605. DOI: 10.18668/NG.2018.08.06.

Kremieniewski M., 2019. O konieczności prowadzenia serwisowych badań parametrów technologicznych zaczynów uszczelniających. Nafta-Gaz, 1: 48-55. DOI:10.18668/NG.2019.01.07.

Kremieniewski M., Rzepka M., 2017. Celowość prowadzenia prac badawczych nad nowymi środkami obniżającymi filtrację zaczynów cementowych. Nafta-Gaz, 8: 583-590. DOI: 10.18668/ NG.2017.08.05.

Kremieniewski M., Stryczek S., Wiśniowski R., Rzepka M., Gonet A., 2017. Wpływ dodatku montmorylonitu/bentonitu/ na parametry świeżego i stwardniałego zaczynu cementowego. AGH Drilling, Oil, Gas, 34: 323-334.
Nelson E.B. et al., 1990. Well Cementing. Schlumberger Educational Service, Houston, Teksas, USA.

Peng Ya, Jacobsen S., 2013. Influence of water/cement ratio, admixtures and filler on sedimentation and bleeding of cement paste. Cement and Concrete Research, 54: 133-142. DOI: 10.1016/j. cemconres.2013.09.003.

Stryczek S. (red.), Wiśniowski R., Uliasz-Misiak B., Złotkowski A., Kotwica Ł., Rzepka M., Kremieniewski M., 2016. Studia nad doborem zaczynów uszczelniających w warunkach wierceń w basenie pomorskim. Monografia sfinansowana przez NCBiR $w$ ramach projektu naukowo-badawczego Optidrilltec z programu Blue Gas - Polski Gaz Łupkowy; Wydawnictwa AGH, Kraków.

Stryczek S., Gonet A., Wiśniowski R., 2005. Wpływ wybranego dodatku mineralnego na własności technologiczne zaczynów cementowych. Wiertnictwo Nafta Gaz, 22/1: 333-341.

Stryczek S., Wiśniowski R., Gonet A., Ferens W., 2009. Parametry reologiczne świeżych zaczynów uszczelniających w zależności od czasu ich sporządzania. Wiertnictwo, Nafta, Gaz, 26/1-2: 369-382.

Stryczek S., Wiśniowski R., Gonet A., Złotkowski A., 2014. The influence of time of rheological parameters of fresh cement slurries. AGH Drilling, Oil, Gas, 31: 123-133. DOI 10.7494/ drill.2014.31.1.123.

Wiśniowski R., Stryczek S., Skrzypaszek K., 2007. Kierunki rozwoju badań nad reologią płynów wiertniczych. Wiertnictwo, Nafta, Gaz, 24: 595-607.

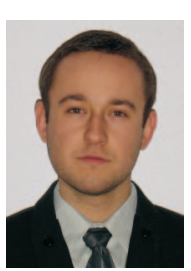

Dr inż. Marcin KREMIENIEWSKI

Adiunkt w Zakładzie Technologii Wiercenia Instytut Nafty i Gazu - Państwowy Instytut Badawczy ul. Lubicz $25 \mathrm{~A}$

31-503 Kraków

E-mail: marcin.kremieniewski@inig.pl

\section{OFERTA BADAWCZA ZAKŁADU TECHNOLOGII EKSPLOATACJI PŁYNÓW ZŁOŻOWYCH}

- optymalizacja procesów wydobycia i przygotowania do transportu ropy i gazu;

- bioremediacja gruntów, odpadów wiertniczych i eksploatacyjnych zanieczyszczonych substancjami ropopochodnymi;

- rekultywacja terenów skażonych substancjami ropopochodnymi;

- opracowywanie technologii oczyszczania ścieków eksploatacyinych i wód ztożowych z zanieczyszczeń ropopochodnych;

- badania i dobór inhibitorów parafinowo-hydratowych oraz deemulgatorów stosowanych w procesach eksploatacii ztóż węglowodorów;

- monitorowanie zmian zawartości związków siarki w podziemnych magazynach gazu i opracowanie koncepcji dziatań zapobiegających powstawaniu siarkowodoru w złożu;

badania sktadu chemicznego ptynów złożowych;

- wykonywanie kart katalogowych oraz opracowanie opinii bezpieczeństwa użytkowania środków chemicznych, stosowanych podczas zabiegów intensyfikacyjnych i eksploatacyjnych w warunkach otworowych;

- analizy zanieczyszczeń gleby i ścieków, odpadów wiertniczych i eksploatacyjnych.

Kierownik: dr hab. inż. Teresa Steliga, prof. INIG-PIB Adres: ul. Armii Krajowej 3, 38-400 Krosno Telefon: 1343660 29, 134368941 w. 5222 Faks: 134367971 E- mail: teresa.steliga@inig.pl

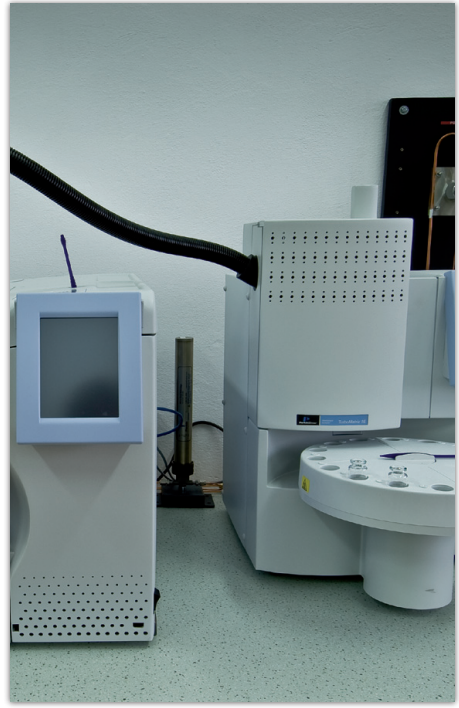

INSTYTUT NAFTY I GAZU - Państwowy Instytut Badawczy 